\title{
Enhancement of Ethanol Oxidation Reaction on Pt (PtSn)-Activated Nickel Foam Through In situ Formation of Nickel Oxy-Hydroxide Layer
}

\author{
Boguslaw Pierozynski ${ }^{1}$. Tomasz Mikolajczyk ${ }^{1}$
}

Published online: 27 February 2017

(C) The Author(s) 2017. This article is published with open access at Springerlink.com

\begin{abstract}
The present paper reports on a significant enhancement of ethanol oxidation reaction (EOR), investigated on $\mathrm{Pt}$ and PtSn-modified nickel foam electrodes, realized via in situ formation of surface nickel oxy-hydroxide layer in $0.1 \mathrm{M}$ $\mathrm{NaOH}$ solution. In the presence of ethanol in electrolyte, adsorbed $\mathrm{C}_{2} \mathrm{H}_{5} \mathrm{OH}$ molecules (and/or its oxidation intermediates) prevent $\mathrm{Pt}(\mathrm{PtSn})$ sites from their extensive dissolution upon prolonged surface electrooxidation of $\mathrm{Ni}$ foam electrode. The above was elucidated through cyclic voltammetry examinations and a.c. impedance-derived charge transfer resistance parameter values. Surface topography and the presence of catalytic additives were revealed from the combined scanning electron microscopy (SEM) and energy dispersive $\mathrm{x}$-ray spectroscopy (EDX) analyses.
\end{abstract}

Keywords $\mathrm{Pt}(\mathrm{PtSn})$-modified nickel foam $\cdot$ Nickel oxy-hydroxide $\cdot$ Ethanol oxidation reaction $\cdot$ Electrochemical impedance spectroscopy $\cdot$ Cyclic voltammetry

\section{Introduction}

Electrooxidation of aliphatic alcohols (e.g. methanol and ethanol) attracts significant interest because of its potential application into energy conversion technologies, i.e. direct alcohol fuel cells (DAFCs). Ethanol is a renewable fuel, as it could be produced by fermentation of sugar-containing biomass. In

Boguslaw Pierozynski

bogpierozynski@yahoo.ca

1 Department of Chemistry, Faculty of Environmental Management and Agriculture, University of Warmia and Mazury in Olsztyn, Plac Lodzki 4, 10-727 Olsztyn, Poland fact, in addition to being relatively non-toxic, ethanol is characterized by about $30 \%$ greater energy density than $\mathrm{CH}_{3} \mathrm{OH}$, its major competitor. Ethanol oxidation reaction (EOR) is a complex anodic process, which involves dissociation of preadsorbed ethanol molecules to produce surface-adsorbed carbon monoxide $\left(\mathrm{CO}_{\mathrm{ad}}\right)$ species and further oxidation of $\mathrm{C}_{2} \mathrm{H}_{5} \mathrm{OH}$ to form (apart from numerous intermediates and by-products) two major chemicals, namely acetaldehyde and acetic acid (Pathway I: $4 \mathrm{e}^{-}$). In fact, most of these products might become adsorbed on the catalyst surface, and thus, quantitative cleavage of the $\mathrm{C}-\mathrm{C}$ bond (in order to finally generate $\mathrm{CO}_{2}$ Pathway II: $12 \mathrm{e}^{-}$) in an ethanol molecule constitutes a key technical problem [1-8].

Pathway I [7]:

$\mathrm{CH}_{3} \mathrm{CH}_{2} \mathrm{OH} \rightarrow\left[\mathrm{CH}_{3} \mathrm{CH}_{2} \mathrm{OH}\right]_{\mathrm{ad}} \rightarrow \mathrm{CH}_{3} \mathrm{CHO} \rightarrow$ $\mathrm{CH}_{3} \mathrm{COOH}$

a) $\mathrm{CH}_{3}-\mathrm{CH}_{2} \mathrm{OH}+\mathrm{H}_{2} \mathrm{O} \rightarrow \mathrm{CH}_{3}-\mathrm{COOH}+4 \mathrm{H}^{+}+4 \mathrm{e}^{-}$

b) $\mathrm{CH}_{3}-\mathrm{CH}_{2} \mathrm{OH} \rightarrow \mathrm{CH}_{3}-\mathrm{CHO}+2 \mathrm{H}^{+}+2 \mathrm{e}^{-}$

$$
\begin{aligned}
& \text { Pathway II [7]: } \\
& \mathrm{CH}_{3} \mathrm{CH}_{2} \mathrm{OH} \rightarrow\left[\mathrm{CH}_{3} \mathrm{CH}_{2} \mathrm{OH}\right]_{\mathrm{ad}} \rightarrow \mathrm{CH}_{\mathrm{x}}+\mathrm{CO} \rightarrow \mathrm{CO}_{2}
\end{aligned}
$$

a) $\mathrm{CH}_{3}-\mathrm{CH}_{2} \mathrm{OH}+3 \mathrm{H}_{2} \mathrm{O} \rightarrow 2 \mathrm{CO}_{2}+12 \mathrm{H}^{+}+12 \mathrm{e}^{-}$

b) $\mathrm{CH}_{3}-\mathrm{CH}_{2} \mathrm{OH}+5 \mathrm{H}_{2} \mathrm{O} \rightarrow 2 \mathrm{HCO}_{3}^{-}+14 \mathrm{H}^{+}+12 \mathrm{e}^{-}$

c) $\mathrm{CH}_{3}-\mathrm{CH}_{2} \mathrm{OH}+5 \mathrm{H}_{2} \mathrm{O} \rightarrow 2 \mathrm{CO}_{3}{ }^{2-}+16 \mathrm{H}^{+}+12 \mathrm{e}^{-}$

Significant facilitation of the EOR's kinetics in basic environments [4, 9-11] enabled application of non-noble and highly corrosion-resistant metals, such as different forms of nickel $[12,13]$. Thus, employment of highly modifiable, large specific surface area nickel foam could be a key point in the development of low noble metal level and highly electroactive catalyst composites for alkaline direct ethanol fuel cells [14-16]. In addition, nickel foam itself could be made 
catalytic for alcohol oxidation reaction through the surface formation of extensive oxide/hydroxide layer [5, 17-19]. Nickel foams are usually produced by chemical vapour deposition (CVD), physical vapour deposition (PVD) and electrochemical or electroless deposition method with a polyurethane foam precursor [16, 20-22]. Extensive structural and electrochemical characterizations of the CVD-based nickel foam were published by Grden et al. [21] and by van Drunen et al. [22, 23].

Platinum [4, 24-28] and especially PtSn [1, 2, 27, 29-32] catalysts are well-known to exhibit superior electrocatalytic properties towards the EOR. Thus, in this contribution, Ptand PtSn-modified Ni foam electrodes were prepared by means of spontaneous deposition methods [16, 30, 33, 34]. Such obtained catalyst materials were then subjected to in situ formation of surface nickel oxy-hydroxide layer via extended cyclic voltammetry treatments, carried out in $0.1 \mathrm{M} \mathrm{NaOH}$ solution, in the presence of $0.5 \mathrm{M}$ ethanol.

\section{Experimental}

All electrochemical work was performed in a threecompartment Pyrex glass cell. The cell contained three electrodes: a Ni foam-based working electrode (WE) in a central part, a reversible $\mathrm{Pd}(0.5 \mathrm{~mm}$ diameter, $99.9 \% \mathrm{pu}-$ rity, Aldrich) hydrogen electrode (RHE: denoted as $\mathrm{Pd} / \mathrm{H}_{2}$ ) as reference and a $\mathrm{Pt}$ (1.0 mm diameter, $99.9998 \%$ purity, Johnson Matthey, Inc.) counter electrode (CE), both positioned in separate compartments. WEs were prepared from MTI nickel foam having the following: purity $>99.99 \% \mathrm{Ni}$; thickness, $1.6 \mathrm{~mm}$; surface density, $346 \mathrm{~g} \mathrm{~m}^{-2}$; porosity $>95 \%$ and mass of ca. $43 \mathrm{mg}(1.1 \times 1.1 \mathrm{~cm})$ per sample. The electrochemically active surface area of the MTI foam has been estimated at $19.2 \mathrm{~cm}^{2}\left(548 \mathrm{~cm}^{2} \mathrm{~g}^{-1}\right)$ in recent work from this laboratory [35]. In short, freshly cut nickel foam samples were subjected to acetone and $\mathrm{CH}_{2} \mathrm{Cl}_{2}$ wash (both for $15 \mathrm{~min}$ under ultrasonication), following air drying and acid etching in $2 \mathrm{M} \mathrm{HCl}$ (for $15 \mathrm{~min}$ at $60^{\circ} \mathrm{C}$ ) [36]. Spontaneous deposition of $\mathrm{Pt}$ was performed by dipping previously pretreated $\mathrm{Ni}$ foam electrodes in $0.005 \mathrm{M}$ chloroplatinic acid hexahydrate: CPAH, Sigma-Aldrich $\left(\mathrm{pH}=1.0, t_{\text {dep. }}=60 \mathrm{~s}\right.$ and $\left.T_{\text {dep. }}=293 \pm 1 \mathrm{~K}\right)$. On the other hand, PtSn deposition was carried out in a mixture of $0.005 \mathrm{M} \mathrm{CPAH}$ and $0.0025 \mathrm{M} \mathrm{SnCl}_{2}$, anhydrous pure p.a., Chempur $\left(\mathrm{pH}=1.0, t_{\mathrm{dep}}=60 \mathrm{~s}\right.$ and $\left.T_{\text {dep. }}=293 \pm 1 \mathrm{~K}\right)$.

Electrochemical impedance spectroscopy and cyclic voltammetry techniques were employed in this work. All measurements were performed at room temperature by means of Solartron 12,608 W Full Electrochemical System. For a.c. impedance measurements, the generator provided an output signal of $5 \mathrm{mV}$ and the frequency range was swept between $1.0 \times 10^{5}$ and $0.1 \mathrm{~Hz}$. The instruments were controlled by ZPlot 2.9 (or Corrware 2.9) software for Windows (Scribner Associates, Inc.). Typically, three impedance measurements were conducted at each potential value, independently at two foam electrodes. Reproducibility of such-obtained results was usually about $10 \%$. Data analysis was carried out with ZView 2.9 (Corrview 2.9) software packages, where the impedance spectra were fitted using a complex, non-linear, least squares immittance fitting program LEVM 6 [37]. All other experimental details, i.e. preparation of supporting electrolyte $\left(0.5 \mathrm{M} \mathrm{C}_{2} \mathrm{H}_{5} \mathrm{OH} / \mathrm{Stanlab}\right.$, pure, p.a. in $0.1 \mathrm{M}$ $\mathrm{NaOH} / \mathrm{AESAR}, 99.996 \%$ pellets), pretreatments applied to electrochemical cell and reference/counter electrodes, were previously described in Refs. 11, 36, 38.

\section{Results and Discussion}

\section{SEM and EDX Characterizations of Pt- and PtSn-Modified Nickel Foam Electrodes}

Figure 1a, b below shows SEM micrograph pictures and EDX patterns of MTI-manufactured, Pt-modified nickel foam (at $\times 10,000$ magnification), taken for a fresh electrode (Fig. 1a) and after 40 cyclic voltammetry (CV) sweeps, carried out over the potential range of 0.05 $2.20 \mathrm{~V}$ vs. RHE in $0.1 \mathrm{M} \mathrm{NaOH}$ solution (in the presence of $0.5 \mathrm{M}$ ethanol, Fig. 1b). In the latter case, extended cyclic voltammetry treatment resulted in in situ formation of surface nickel oxide (oxy-hydroxide) layer, evidenced through surface roughening and increased oxygen content recorded in Fig. $1 \mathrm{~b}$ as compared to those observed in Fig. 1a. Furthermore, Fig. 1c illustrates SEM micrograph picture $(\times 10,000$ magnification $)$ and EDX pattern for a PtSn-activated $\mathrm{Ni}$ foam electrode sample, recorded after $10 \mathrm{CV}$ sweeps over the potential range of $0.05-2.50 \mathrm{~V}$, performed in $0.1 \mathrm{M} \mathrm{NaOH}$, alcohol-based supporting electrolyte. The presence of $\mathrm{Pt}$ and $\mathrm{Sn}$ entities (comparatively to Pt spikes observed in EDX spectra of Fig. 1a, b) could be clearly observed in an EDX micrograph of Fig. 1c.

Furthermore, average quantities of the deposited $\mathrm{Pt}$ and PtSn catalysts on the nickel foam substrate were assessed on the order of $0.3 \mathrm{wt} \%$ by means of a weighing method (for average Ni foam electrode mass of $43 \mathrm{mg}$ ), whereas SEMapproximated catalysts grain size values came to $10.5 \pm 3.2$ and $13.3 \pm 3.5 \mathrm{~nm}$ for the Pt and PtSn deposits, correspondingly (see Ref. 35 for details on the respective procedure). It should be stressed however that platinum distribution was rather non-uniform, where Pt grains typically formed numerous nests on the Ni foam surface (Fig. 1d), thus resulting in highly increased platinum content (derived through the EDX analysis) over that produced by the weighing (see Cyclic 

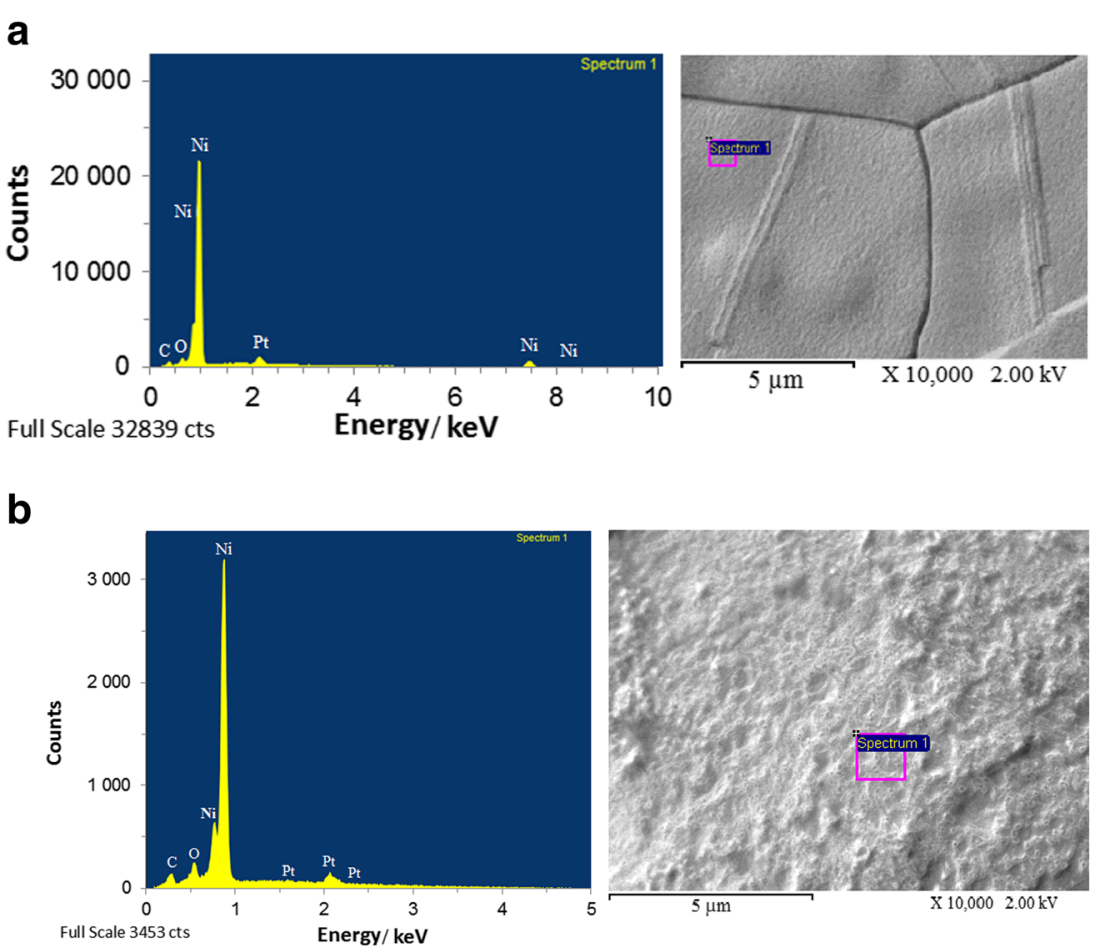

C
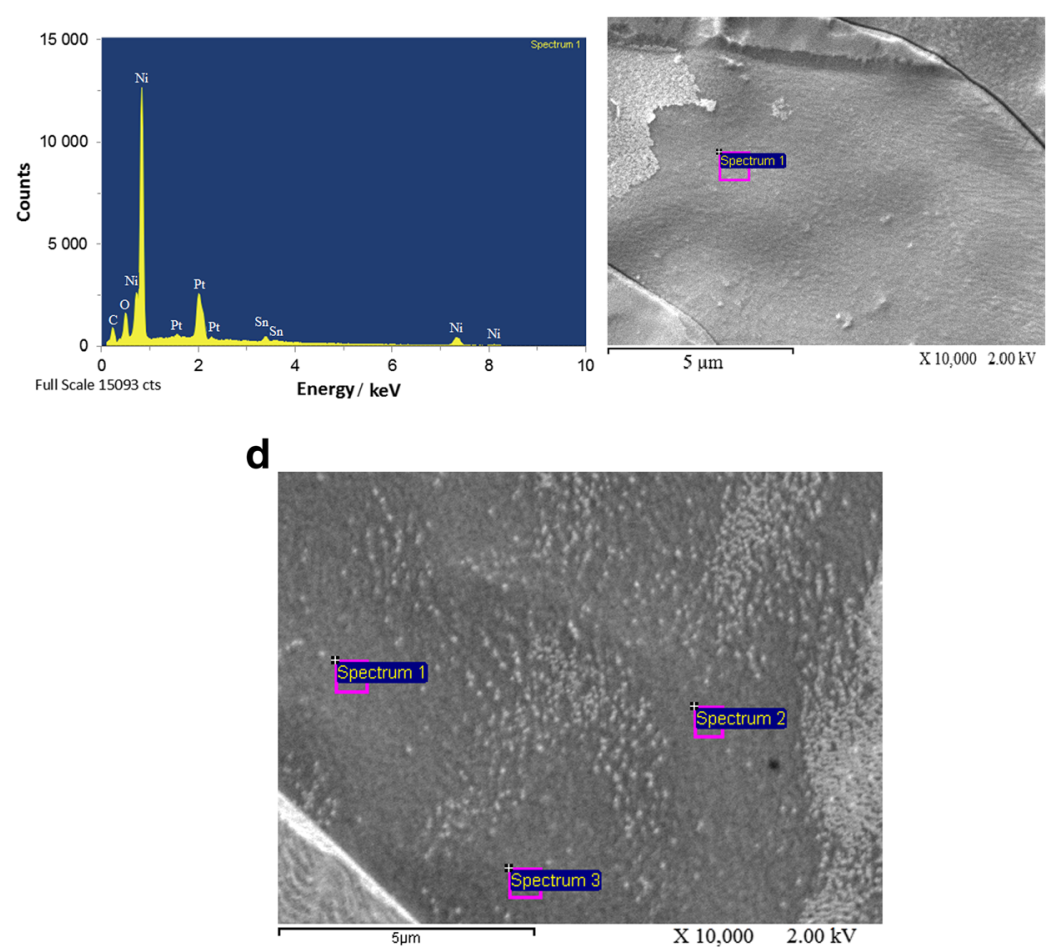

Fig. 1 a SEM micrograph picture and EDX pattern of Pt-modified Ni foam surface (ca. $0.3 \mathrm{wt} \% \mathrm{Pt}$ ), taken at $\times 10,000$ magnification for a fresh electrode. b As in (a), but taken after 40 extended CV sweeps, carried out in $0.1 \mathrm{M} \mathrm{NaOH}$ (in the presence of $0.5 \mathrm{M} \mathrm{C}_{2} \mathrm{H}_{5} \mathrm{OH}$ ). $\mathbf{c}$ As in (b), but taken

Voltammetry Behaviour of Ethanol Oxidation Reaction and Table 1). Furthermore, no estimates on the PtSn atomic ratio after 10 extended CV sweeps, performed on PtSn-modified Ni foam surface. d SEM micrograph picture of Pt-modified Ni foam surface showing Pt nesting effect (ca. $0.3 \mathrm{wt} \% \mathrm{Pt}$ ), taken at $\times 10,000$ magnification after 100 extended $\mathrm{CV}$ sweeps, carried out in $0.1 \mathrm{M} \mathrm{NaOH}$

and the possibility of PtSn alloying were given or discussed in this work $[2,31]$. 
Table 1 EDX-derived (for acceleration voltage of $2.0 \mathrm{kV}$ ) surface elemental (Pt and $\mathrm{O}$ ) composition for Pt-modified Ni foam samples; sample 1-unexposed to electrolyte, sample 2-after oxidation pretreatment: 100 cycles $(0.05-1.90 \mathrm{~V} / \mathrm{RHE})$ in $0.1 \mathrm{M} \mathrm{NaOH}$ at a sweep rate of $200 \mathrm{mV} \mathrm{s}^{-1}$

\begin{tabular}{llcl}
\hline Element & Measurement & Sample 1 & Sample 2 \\
\hline $\mathrm{Pt} / \%$ & 1 & 23.60 & 9.42 \\
& 2 & 20.00 & 9.51 \\
& 3 & 18.70 & 7.66 \\
$\mathrm{O} / \%$ & 1 & 1.30 & 2.36 \\
& 2 & 1.10 & 1.96 \\
& 3 & 1.20 & 2.16 \\
\hline
\end{tabular}

\section{Cyclic Voltammetry Behaviour of Ethanol Oxidation Reaction}

Figure 2a presents the cyclic voltammetric behaviour of ethanol electrooxidation (at $0.5 \mathrm{M} \mathrm{C}_{2} \mathrm{H}_{5} \mathrm{OH}$ ), carried out at room temperature on surface-electrooxidized $(500 \mathrm{CV}$ sweeps between 0.5 and $2.0 \mathrm{~V} / \mathrm{Pd} / \mathrm{H}_{2}$ at a sweep rate of $200 \mathrm{mV} \mathrm{s}^{-1}$, see inset of Fig. 2a) $\mathrm{Ni}$ foam electrode in $0.1 \mathrm{M} \mathrm{NaOH}$ supporting electrolyte. Surface oxidation of ethanol is accomplished through the reaction of $\mathrm{C}_{2} \mathrm{H}_{5} \mathrm{OH}$ molecule with a $\beta-\mathrm{NiOOH}$ species, formed upon prolonged CV cycling (inset of Fig. 2a). Hence, a sharp increase of anodic oxidation current beyond the potential of ca. $1.4 \mathrm{~V}$ is predominantly related to an ongoing process of ethanol surface oxidation reaction (in addition to oxygen evolution reaction). The above follows with significant diminution (and anodic displacement) of $\beta-\mathrm{NiOOH}$ electroreduction charge (see broad peak A in Fig. 2a). These findings are in very good agreement with those presented by Barbosa et al. [5], Motheo et al. [17] and by Kim and Park [18]. It should be stressed however that comprehensive studies of $\mathrm{Ni}$ oxide growth and characterization were published in important papers by van Drunen et al. [22] and by Alsabet et al. [39-41].

On the other hand, progressive in situ formation of nickel oxy-hydroxide layer exhibited significant influence on the process of ethanol electrooxidation. The above could be clearly observed in cyclic voltammetric profiles of Fig. 2b, c, recorded on Pt- and PtSn-activated Ni foam electrode surfaces in $0.1 \mathrm{M} \mathrm{NaOH}$ (in the presence of $0.5 \mathrm{M} \mathrm{C}_{2} \mathrm{H}_{5} \mathrm{OH}$ ), respectively. Thus, for the Pt-activated $\mathrm{Ni}$ foam extended cycling over the potential range of $0.05-2.10 \mathrm{~V} / \mathrm{Pd} / \mathrm{H}_{2}$ caused a radical enhancement of the EOR, which is evidenced in rising of the maximum anodic current density in the voltammogram from about $0.35 \mathrm{~A} \mathrm{~g}^{-1}$ (for cycle no. 1) to over $1.80 \mathrm{~A} \mathrm{~g}^{-1}$ for the 40th cycle (by ca. $\times 5.2$ ). For the PtSn-modified nickel foam electrode, the corresponding maximum anodic current density value reached about $1.75 \mathrm{~A} \mathrm{~g}^{-1}$, just after completion of ten full voltammetric cycles (compare again Fig. 2b, c). It should also be noted that upon voltammetric cycling, the peak potential value of this oxidation peak (widely assigned in literature to the formation of $\mathrm{C}_{2} \mathrm{H}_{5} \mathrm{OH}$ surface oxidation products, principally to acetaldehyde) becomes shifted to more positive potentials, reaching about $1.75 \mathrm{~V}$ for the $\mathrm{Ni}$ foam/Pt electrode (after 40 cycles) and $1.70 \mathrm{~V}$ for the $\mathrm{Ni}$ foam/PtSn after ten voltammetric cycles. Another oxidation peak that appears in the CV profiles (see Fig. 2b, c, potential range ca. 0.50 $0.90 \mathrm{~V}$ ) upon the reverse scan towards the hydrogen reversible potential is generally assigned to the process of surface oxidation of $\mathrm{CO}_{\text {ads. }}$ species [16, 24-26].

However, it could be observed in Fig. 2d that when the nickel oxy-hydroxide layer is formed on the Pt-modified nickel foam in the presence of alcohol in electrolyte, the process of ethanol oxidation is greatly enhanced, as compared to the case, where the EOR is performed on the surface of the Ptactivated $\mathrm{Ni}$ foam that was pre-oxidized (100 CV sweeps at $200 \mathrm{mV} \mathrm{s}^{-1}$ ) in pure $0.1 \mathrm{M} \mathrm{NaOH}$ solution. Hence, for the latter case maximum of the anodic EOR current density value was recorded on the tenth cycle and reached about $40 \%$ of that derived for the former case.

In fact, it seems that surface-electrosorbed ethanol molecules and their oxidation intermediates (primarily available on the Pt sites) are effectively blocking (and thus securing) platinum sites from being disrupted/dissolved $[42,43]$ during an extended cyclic voltammetry-based surface oxidation process. Table 1 shows the EDX-derived surface $(\mathrm{Pt}$ and $\mathrm{O})$ qualitative elemental composition for electrolyte-unexposed and electrooxidized (100 cycles performed over the potential range of $0.05-1.90 \mathrm{~V} / \mathrm{RHE}$ in $0.1 \mathrm{M} \mathrm{NaOH}$, at a sweep rate of $200 \mathrm{mV} \mathrm{s}^{-1}$ ) Pt-modified nickel foam sample. Hence, extended oxidation pretreatment resulted in a radical reduction of Pt content (from an average recorded value of 20.8 to $8.9 \%$ : $\times 2.3$ ) along with a significant increase of oxygen presence (from 1.2 to $2.2 \%$ : $\times 1.8$ ). Similar Pt catalyst 'stabilization effect' to that discussed for the Pt-modified Ni foam in Fig. 2d could also be argued for the PtSn-based composite foam electrode. However, the latter catalyst seems to be much more resistant towards dissolution of Pt (PtSn) entities than the former one was for disruption of Pt sites (compare Fig. 2d, e).

\section{a.c. Impedance Characterization of EOR}

The a.c. impedance spectroscopy behaviour of ethanol electrooxidation reaction (at $0.5 \mathrm{M} \mathrm{C}_{2} \mathrm{H}_{5} \mathrm{OH}$ ) on the Pt- and PtSn-activated Ni foam electrode surfaces in $0.1 \mathrm{M} \mathrm{NaOH}$ is presented in Table 2 and Figs. 3 and 4 below. Thus, the impedance behaviour of the EOR recorded on extensively oxidized $\mathrm{Ni}$ foam electrode is characterized by a single, partial and distorted semicircle, exhibited in the Nyquist impedance spectra (not shown in this work). This semicircle refers to the charge transfer resistance $\left(R_{\mathrm{ct}}\right)$ of the ethanol oxidation reaction (see Table 2 and equivalent circuit in Fig. 3a). The charge 
a

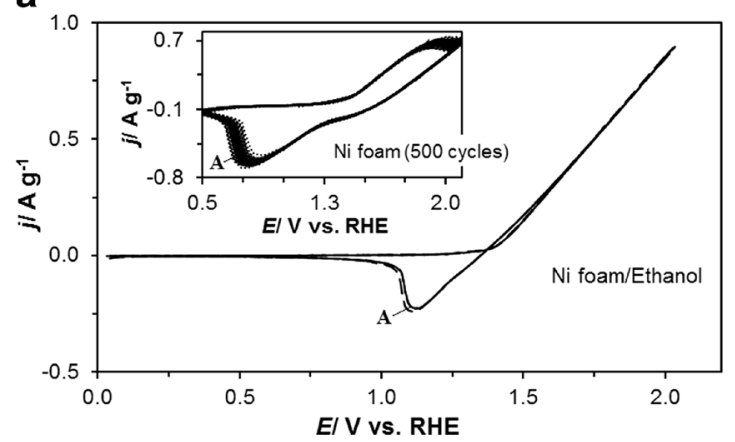

b

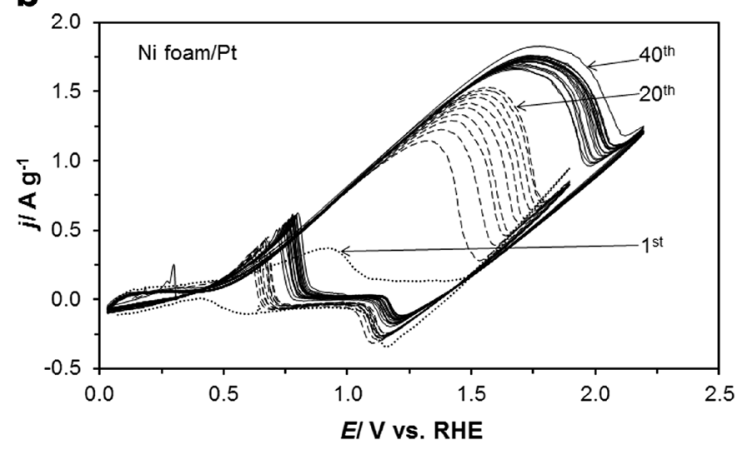

C

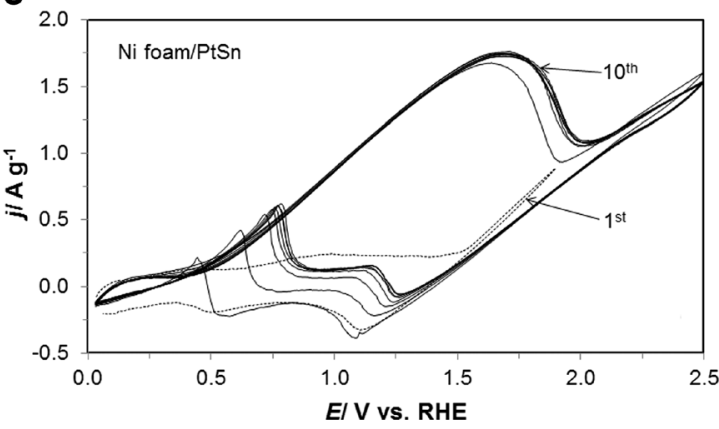

d

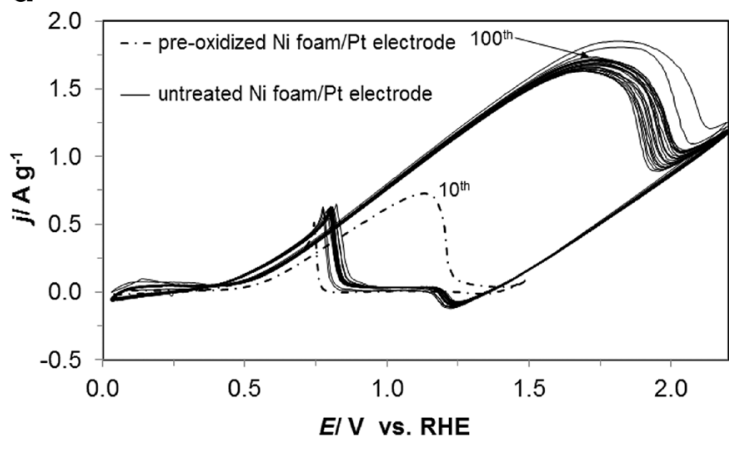

e

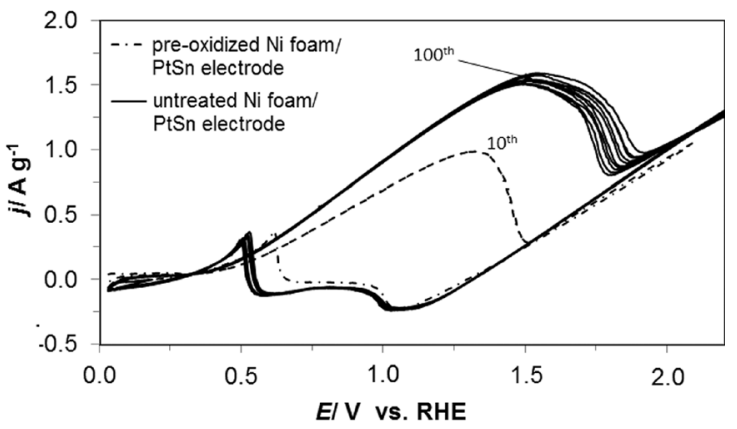

Fig. 2 a Cyclic voltammograms for ethanol electrooxidation on surface pre-oxidized $\mathrm{Ni}$ foam electrode, carried out in $0.1 \mathrm{M} \mathrm{NaOH}$, at a sweep rate of $50 \mathrm{mV} \mathrm{s}^{-1}$ and in the presence of $0.5 \mathrm{M} \mathrm{C}_{2} \mathrm{H}_{5} \mathrm{OH}$ (inset: development of nickel oxy-hydroxide layer on $\mathrm{Ni}$ foam electrode; 500 CV sweeps at $200 \mathrm{mV} \mathrm{s}^{-1}$ ). b Cyclic voltammograms for simultaneous ethanol electrooxidation and formation of nickel oxy-hydroxide layer on Pt-modified $\mathrm{Ni}$ foam electrode, carried out in $0.1 \mathrm{M} \mathrm{NaOH}$ at a sweep rate of $50 \mathrm{mV} \mathrm{s}^{-1}$ and in the presence of $0.5 \mathrm{M} \mathrm{C}_{2} \mathrm{H}_{5} \mathrm{OH}$. c As in (b), but performed on PtSn-modified $\mathrm{Ni}$ foam electrode. d Cyclic

transfer resistance recorded at an onset of the EOR (at $1400 \mathrm{mV}$ ) came to $0.49 \Omega \mathrm{g}$, whereas that derived at $2000 \mathrm{mV}$ (most likely for a combined ethanol oxidation and oxygen evolution processes) reached $0.05 \Omega \mathrm{g}$. Then, the respective double-layer capacitance $\left(C_{\mathrm{dl}}\right)$ parameter exhibited significant reduction from $1,011,854 \mu \mathrm{F} \mathrm{g}^{-1} \mathrm{~s}^{\varphi 1-1}$ at $1400 \mathrm{mV}$ to $608,756 \mu \mathrm{F} \mathrm{g}^{-1} \mathrm{~s}^{\varphi 1-1}$ at $2000 \mathrm{mV}$, where the former one is about $\times 120$ greater than that previously recorded for unmodified MTI nickel foam surface (see Table 2 in Ref. 36). voltammograms for simultaneous ethanol electrooxidation and formation of nickel oxy-hydroxide layer on untreated Pt-modified $\mathrm{Ni}$ foam electrode (carried out in $0.1 \mathrm{M} \mathrm{NaOH}$ at a sweep rate of $50 \mathrm{mV} \mathrm{s}^{-1}$ and in the presence of $0.5 \mathrm{M} \mathrm{C}_{2} \mathrm{H}_{5} \mathrm{OH}$ ) compared with a $\mathrm{CV}$ profile for EOR obtained under analogous experimental conditions, but on pre-oxidized (100 CV sweeps at $200 \mathrm{mV} \mathrm{s}^{-1}$ ) $\mathrm{Ni}$ foam/Pt electrode in pure $\mathrm{NaOH}$ solution; maximum anodic (EOR) current density was recorded on the 10th cycle. e As in (d), but performed on PtSn-modified Ni foam electrode

On the other hand, Table 2 presents the a.c. impedancederived kinetic EOR parameters obtained for the Pt-modified (1st, 10th, 20th, 30th and 40th cycles) and the PtSn-activated (10th cycle) Ni foam electrodes. Thus, the EOR impedance behaviour is characterized by the presence of a single or two partial semicircles in the Nyquist impedance plot. A high frequency and low diameter semicircle corresponds to the process of ethanol electrooxidation $\left(R_{\mathrm{ct}}\right)$, whereas low frequency, large diameter semicircle most likely refers to adsorbed intermediates (see, e.g. Refs. 17, 18 for details) species $\left(R_{\mathrm{Ads}}\right)$, 
Table 2 Resistance and capacitance parameters for electrooxidation of ethanol (at $0.5 \mathrm{M} \mathrm{C}_{2} \mathrm{H}_{5} \mathrm{OH}$ ) on surface-oxidized, pure, Pt-modified and PtSn-activated $\mathrm{Ni}$ foam electrodes in $0.1 \mathrm{M} \mathrm{NaOH}$ supporting solution, obtained by finding equivalent circuits, which best fitted the recorded impedance data, as shown in Fig. 3a-c. The recorded values of dimensionless parameters $\varphi_{1}$ and $\varphi_{2}$ (for the CPE components in
Fig. 3a-c) oscillated between $0.62-0.98$ and $0.74-0.89$, correspondingly (impedance reproducibility usually below $10 \%, \chi^{2}=9 \times 10^{-5}$ to $1 \times 10^{-3}$; lower and upper potential values for all examined configurations refer to onset and maximum of the voltammetric current density for EOR, correspondingly)

\begin{tabular}{|c|c|c|c|c|}
\hline$E / \mathrm{mV}$ & $R_{\mathrm{ct}} / \Omega \mathrm{g}$ & $C_{\mathrm{d} 1} / \mu \mathrm{F} \mathrm{g}^{-1} \mathrm{~s}^{\varphi 1-1}$ & $R_{\mathrm{Ads}} / \Omega \mathrm{g}$ & $C_{\text {Ads }} / \mu \mathrm{F} \mathrm{g}^{-1} \mathrm{~s}^{\varphi 2-1}$ \\
\hline \multicolumn{5}{|c|}{ Ni foam (500 cycles) } \\
\hline 1400 & $0.49 \pm 0.01$ & $1,011,854 \pm 17,707$ & - & - \\
\hline 2000 & $0.05 \pm 0.00$ & $608,756 \pm 46,874$ & - & - \\
\hline \multicolumn{5}{|c|}{ Ni foam/Pt 1 st cycle } \\
\hline 400 & $4.23 \pm 0.11$ & $313,325 \pm 3888$ & - & - \\
\hline 900 & $0.13 \pm 0.01$ & $90,365 \pm 4507$ & $3.31 \pm 0.20$ & $108,848 \pm 6231$ \\
\hline \multicolumn{5}{|c|}{$\mathrm{Ni}$ foam/Pt 10th cycle } \\
\hline 600 & $1.15 \pm 0.04$ & $223,020 \pm 8807$ & - & - \\
\hline 1250 & $0.09 \pm 0.01$ & $108,926 \pm 12,036$ & $21.83 \pm 2.98$ & $244,511 \pm 12,847$ \\
\hline \multicolumn{5}{|c|}{$\mathrm{Ni}$ foam/Pt 20th cycle } \\
\hline & & & $R_{\mathrm{O}} / \Omega \mathrm{g}$ & $L / \mathrm{H}$ \\
\hline \multirow[t]{2}{*}{700} & $1.11 \pm 0.05$ & $173,065 \pm 11,048$ & $0.71 \pm 0.04$ & $20.3 \pm 1.5$ \\
\hline & & & $R_{\text {Ads }} / \Omega \mathrm{g}$ & $C_{\mathrm{Ads}} / \mu \mathrm{F} \mathrm{g}^{-1} \mathrm{~s}^{\varphi 2-1}$ \\
\hline 1550 & $0.05 \pm 0.00$ & $656,721 \pm 94,725$ & $0.11 \pm 0.00$ & $1,610,488 \pm 138,297$ \\
\hline \multicolumn{5}{|c|}{$\mathrm{Ni}$ foam/Pt 30th cycle } \\
\hline & & & $R_{\mathrm{O}} / \Omega \mathrm{g}$ & $L / \mathrm{H}$ \\
\hline \multirow[t]{2}{*}{750} & $1.00 \pm 0.05$ & $158,148 \pm 11,475$ & $0.52 \pm 0.04$ & $14.3 \pm 0.9$ \\
\hline & & & $R_{\mathrm{Ads}} / \Omega \mathrm{g}$ & $C_{\mathrm{Ads}} / \mu \mathrm{F} \mathrm{g}{ }^{-1} \mathrm{~s}^{\varphi 2-1}$ \\
\hline 1650 & $0.04 \pm 0.00$ & $578,441 \pm 31,423$ & $0.08 \pm 0.00$ & $1,381,698 \pm 74,441$ \\
\hline \multicolumn{5}{|c|}{$\mathrm{Ni}$ foam/Pt 40th cycle } \\
\hline & & & $R_{\mathrm{o}} / \Omega \mathrm{g}$ & $L / \mathrm{H}$ \\
\hline \multirow[t]{2}{*}{800} & $1.19 \pm 0.07$ & $110,046 \pm 9443$ & $0.54 \pm 0.03$ & $9.9 \pm 0.7$ \\
\hline & & & $R_{\mathrm{Ads}} / \Omega \mathrm{g}$ & $C_{\mathrm{Ads}} / \mu \mathrm{F} \mathrm{g}{ }^{-1} \mathrm{~s}^{\varphi 2-1}$ \\
\hline 1750 & $0.03 \pm 0.00$ & $552,767 \pm 41,527$ & $0.08 \pm 0.01$ & $1,102,139 \pm 82,800$ \\
\hline \multicolumn{5}{|c|}{$\mathrm{Ni}$ foam/PtSn 10th cycle } \\
\hline & & & $R_{\mathrm{o}} / \Omega \mathrm{g}$ & $L / \mathrm{H}$ \\
\hline \multirow[t]{2}{*}{800} & $0.69 \pm 0.03$ & $218,743 \pm 16,918$ & $0.53 \pm 0.03$ & $9.7 \pm 0.8$ \\
\hline & & & $R_{\mathrm{Ads}} / \Omega \mathrm{g}$ & $C_{\text {Ads }} / \mu \mathrm{F} \mathrm{g}^{-1} \mathrm{~s}^{\varphi 2-1}$ \\
\hline 1700 & $0.02 \pm 0.00$ & $412,152 \pm 19,371$ & $0.10 \pm 0.00$ & $1,314,236 \pm 24,512$ \\
\hline
\end{tabular}

generated upon ethanol oxidation (see Table 2, equivalent circuit in Figs. $3 \mathrm{~b}$ and 4 for details). Hence, for the Ptactivated foam, the charge transfer resistance $\left(R_{\mathrm{ct}}\right)$ parameter for the anodic peak current density potential exhibits significant reduction upon prolonged cycling: from $0.13 \Omega \mathrm{g}$ for the first cycle to reach $0.03 \Omega \mathrm{g}$ after 40 cycles (ca. $\times 4.3$ ). Simultaneously, the $C_{\mathrm{dl}}$ parameter recorded for the respective $\mathrm{CV}$ sweeps and potentials increased by about $\times 6.1$. On the other hand, for enhanced EOR (cycles 20 through 40), the adsorption charge transfer resistance $\left(R_{\mathrm{Ads}}\right)$ oscillated around $0.1 \Omega \mathrm{g}$, whereas pseudocapacitance $\left(C_{\mathrm{Ads}}\right)$ parameter dramatically increased to the level of $1,102,139-$ $1,610,488 \mu \mathrm{F} \mathrm{g}^{-1} \mathrm{~s}^{\varphi 2-1}$. In fact, for the potentials corresponding to the sharp anodic peak (ca. $0.50-0.85 \mathrm{~V} / \mathrm{Pd} / \mathrm{H}_{2}$, Fig. $2 \mathrm{~b}$ ) the impedance behaviour exhibited an inductive loop over the low frequency end (see the recorded inductive resistance, $R_{\mathrm{o}}$, and inductance, $L$, parameters in Table 2 and Fig. 3c). This behaviour is analogous to that reported by other authors on the process of ethanol electrooxidation at composite catalyst materials $[4,31,44]$. The presence of the inductive loop (at ca. $700-800 \mathrm{mV} / \mathrm{Pd} / \mathrm{H}_{2}$ ) is presumably associated with the process of oxidative removal of $\mathrm{CO}_{\text {ads }}$ species from the catalyst surface, leading simultaneously to the release of the catalyst active sites.

In contrast, for the PtSn-modified foam electrode, the $R_{\mathrm{ct}}$ resistance of $0.02 \Omega \mathrm{g}$ (in reference to the $C_{\mathrm{dl}}$ value of $412,152 \mu \mathrm{F} \mathrm{g}^{-1} \mathrm{~s}^{\varphi 1-1}$ ) was recorded at $1700 \mathrm{mV}$, already after ten full CV sweeps. The latter is in-line with previous findings 

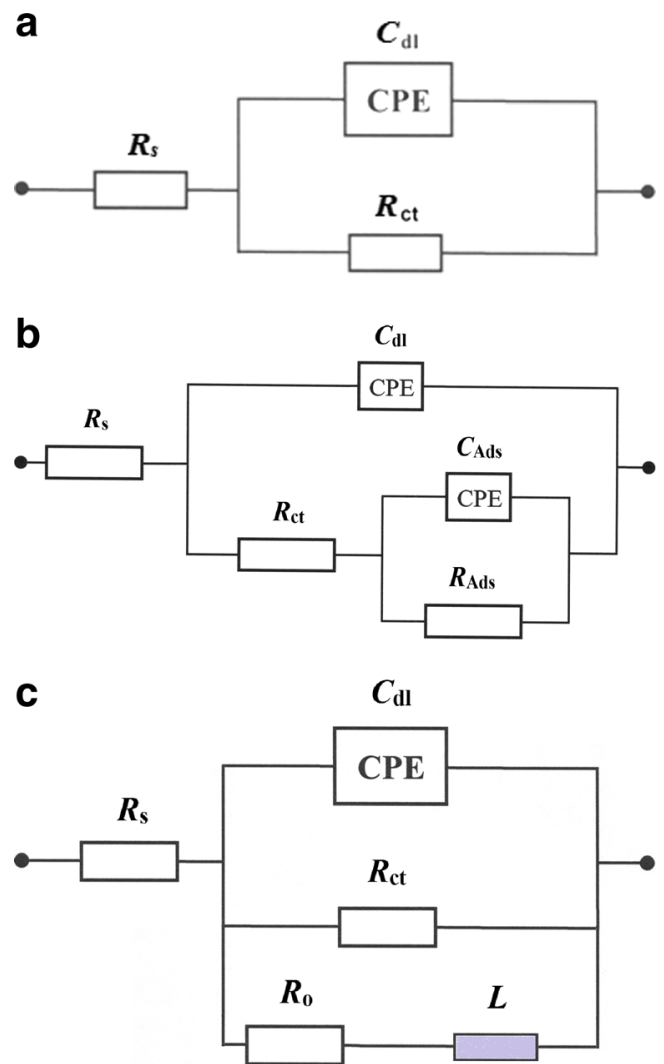

Fig. 3 Three equivalent circuits used for fitting the obtained a.c. impedance spectroscopy data, where $R_{\mathrm{s}}$ is solution resistance; $C_{\mathrm{dl}}$ is double-layer capacitance (represented as CPE: constant phase element to account for distributed capacitance); $R_{\mathrm{ct}}$ is charge transfer resistance parameter for electrooxidation of ethanol; $C_{\mathrm{Ads}}$ and $R_{\mathrm{Ads}}$ are pseudocapacitance (given as CPE) and resistance of adsorption intermediates, respectively; $R_{\mathrm{o}}$ and $L$ are inductive resistance and inductance parameters, correspondingly

on the superior EOR performance of PtSn vs. Pt catalyst deposits [30,31]. Thus, it is supposed that the Sn role in facilitation of the EOR is related to enhancement of the removal of adsorbed intermediates from the Pt sites [30].

Interestingly, in a previously mentioned paper [5], Barbosa et al. have recently studied ethanol electrooxidation (at $0.5 \mathrm{M}$ $\mathrm{C}_{2} \mathrm{H}_{5} \mathrm{OH}$ ) on polycrystalline Ni electrode in $1 \mathrm{M} \mathrm{NaOH}$ solution. There, a maximum value of anodic current density of $17 \mathrm{~mA} \mathrm{~cm}{ }^{-2}$ was recorded at $1.55 \mathrm{~V}$ vs. $\mathrm{Pd} / \mathrm{H}_{2}$ (compare with ca. $4 \mathrm{~mA} \mathrm{~cm}^{-2}$ for the Pt-modified Ni foam electrode with a surface area roughly estimated-based on the a.c. impedancederived double-layer capacitance parameter $[45,46]$ at $17.9 \mathrm{~cm}^{2}$ in this work [36]). In addition, Huang et al. [47] presented a comparison for the EOR performance of various (primarily Pt/Ni-related) catalysts and experimental conditions, where Pt-activated $\mathrm{NiO} / \mathrm{C}$ composite electrode exhibited a maximum of anodic voltammetric current density of $10 \mathrm{~mA} \mathrm{~cm}{ }^{-2}$, recorded in $1 \mathrm{M} \mathrm{KOH} / 1 \mathrm{M} \mathrm{C}_{2} \mathrm{H}_{5} \mathrm{OH}$ solution. On the other hand, Motheo et al. [17], Kim and Park [18] and Gupta et al. [31] provided comprehensive a.c. impedance

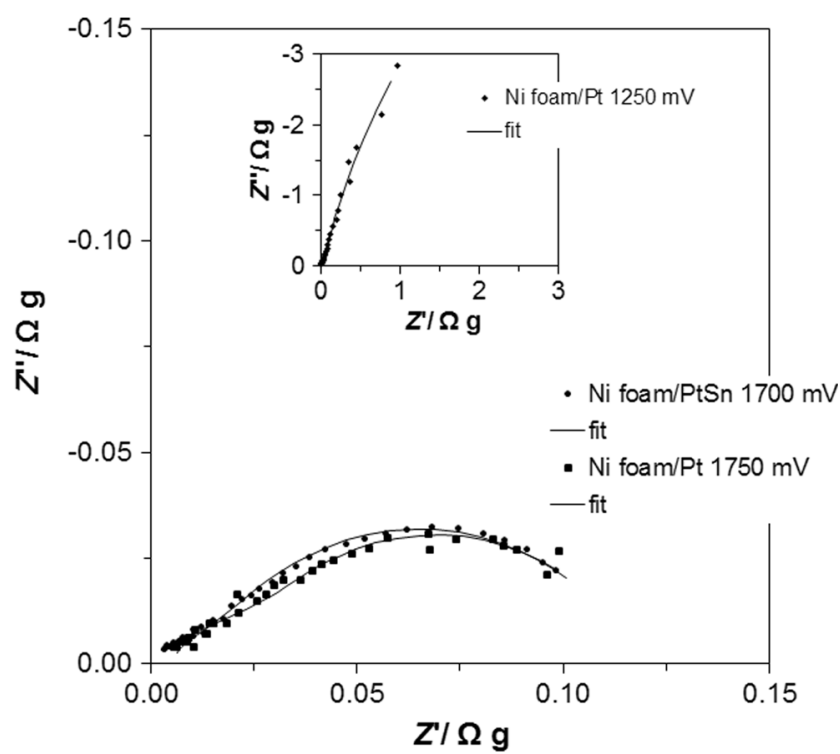

Fig. 4 Complex plane impedance plots for Pt- and PtSn-modified Ni foam electrodes in contact with $0.1 \mathrm{M} \mathrm{NaOH}$, in the presence of $0.5 \mathrm{M}$ $\mathrm{C}_{2} \mathrm{H}_{5} \mathrm{OH}$, recorded at the stated potential values. The solid lines correspond to representation of the data according to the equivalent circuit shown in Fig. 3b

examinations of the EOR (under analogous experimental conditions) on surface-electrooxidized $\mathrm{Ni}$ electrodes and $\mathrm{PtSn}$ catalyst entities, correspondingly. Hence, the recorded there maximum ethanol oxidation voltammetric current densities came to about 2.5 [17] and $6 \mathrm{~mA} \mathrm{~cm}$ c $^{-2}$ [18]. On the other hand, minimum values of the recorded charge transfer resistance parameter for the process of ethanol oxidation reached 58.5 [17] and $42.9 \Omega \mathrm{cm}^{2}$ [18] (compare with 204, 12.5 and $8.3 \Omega \mathrm{cm}^{2}$ values of the $R_{\mathrm{ct}}$ parameter derived in this work for electrooxidized pure nickel foam and Pt-modified and PtSnactivated/in situ electrooxidized $\mathrm{Ni}$ foam electrodes, correspondingly).

Finally, complementary impedance study (carried out down to the frequency of $10 \mathrm{mHz}$ ) and cyclic voltammetry (sweep rate dependent) examinations of the EOR were conducted on electrooxidized $\mathrm{Ni}$ foam/Pt electrode. The impedance experiments (performed for 0.05 and $0.5 \mathrm{M}$ ethanol concentrations in $0.1 \mathrm{M} \mathrm{NaOH}$ solution) showed practically no diffusion-type behaviour (not shown in this work) at all probed potential values (900-1300 and $1200-1850 \mathrm{mV}$ vs. RHE for 0.05 and $0.5 \mathrm{M}$ ethanol concentrations, respectively), in reference to the anodic oxidation peak observed in Fig. $2 b$. Similarly, no conclusions could be made about the involvement of mass transport control from examining the sweep rate characteristics of the voltammetric's maximum anodic current density peak value. In fact, for both plots [peak current density vs. sweep rate (Fig. 5a), as well as the peak current density vs. (sweep rate $)^{1 / 2}$ (Fig. 5b)], the deviations from linearity are similar and rather insignificant, also based on the derived $R^{2}$ parameter values. 

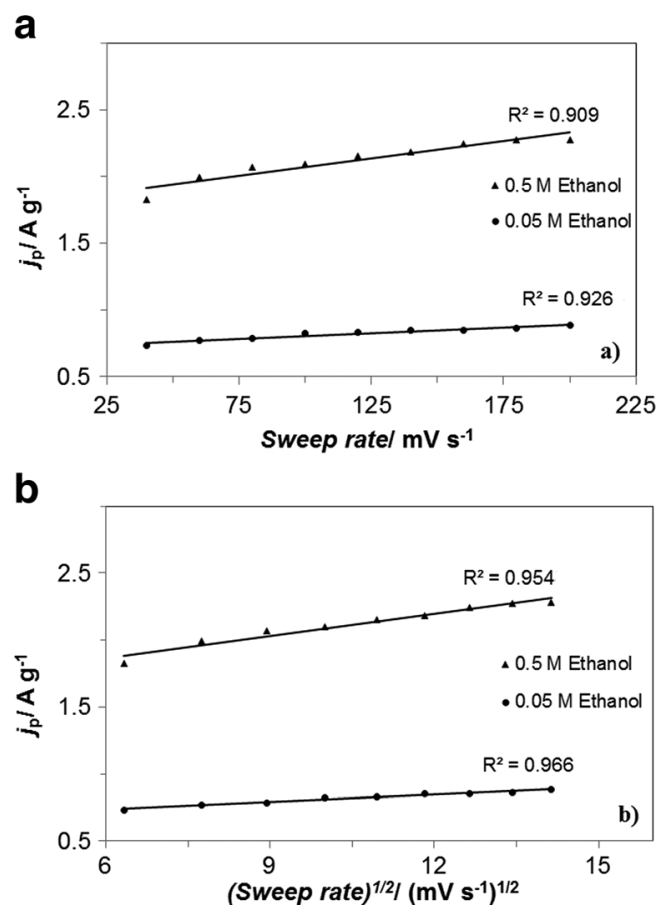

Fig. 5 a Peak anodic current density value vs. sweep rate for electrooxidized, Pt-modified Ni foam electrode in contact with $0.1 \mathrm{M}$ $\mathrm{NaOH}$, in the presence of 0.05 and $0.5 \mathrm{M}$ ethanol. b As in (a), but peak anodic current density value vs. square root of sweep rate

\section{Conclusions}

Extended surface area, Pt- and PtSn-modified (ca. $0.3 \mathrm{wt} \% \mathrm{Pt}$ or PtSn) and electrooxidized nickel foam samples proved to possess significant catalytic properties towards ethanol oxidation in $0.1 \mathrm{M} \mathrm{NaOH}$ supporting electrolyte. Nickel surface electroxidation (formation of surface nickel oxy-hydroxide species) for catalyst-modified Ni foam is most efficient when combined with the process of ethanol oxidation. There, surface-adsorbed ethanol molecules and their oxidation intermediates play an effective role in securing platinum $(\mathrm{PtSn})$ catalyst sites from being disrupted/dissolved upon prolonged cyclic voltammetry-based surface oxidation process.

Such composite catalysts could potentially find interest from the perspective of the development of alkaline direct ethanol (alcohol) fuel cell. However, as possible formation of carbonate constitutes a major problem for these devices, the above requires that special measures be considered and undertaken, including $\mathrm{CO}_{2}$ purging mechanism, air filtration and application of an anion-exchange membrane.

Open Access This article is distributed under the terms of the Creative Commons Attribution 4.0 International License (http:// creativecommons.org/licenses/by/4.0/), which permits unrestricted use, distribution, and reproduction in any medium, provided you give appropriate credit to the original author(s) and the source, provide a link to the Creative Commons license, and indicate if changes were made.

\section{References}

1. S.Q. Song, W.J. Zhou, Z.H. Zhou, L.H. Jiang, G.Q. Sun, Q. Xin, V. Leontidis, S. Kontou, P. Tsiakaras, Int. J. Hydrog. Energy 30, 995 (2005)

2. E.V. Spinace, M. Linardi, A.O. Neto, Electrochem. Commun. 7, $365(2005)$

3. Y. Suo, I.M. Hsing, J. Power Sources 196, 7945 (2011)

4. B. Pierozynski, Int. J. Electrochem. Sci. 7, 4261 (2012)

5. A.F.B. Barbosa, V.L. Oliveira, J. van Drunen, G. Tremiliosi-Filho, J. Electroanal. Chem. 746, 31 (2015)

6. S.S. Gupta, J. Datta, J. Electroanal. Chem. 594, 65 (2006)

7. Y. Wang, S. Zou, W.B. Cai, Catalysts 5, 1507 (2015)

8. H.A. Asiri, A.B. Anderson, J. Electrochem. Soc. 162(1), F115 (2015)

9. A. Dutta, S.S. Mahapatra, J. Datta, Int. J. Hydrog. Energy 36, 14898 (2011)

10. R.M. Modibedi, T. Masombuka, M.K. Mathe, Int. J. Hydrog. Energy 36, 4664 (2011)

11. B. Pierozynski, Int. J. Electrochem. Sci. 7, 6406 (2012)

12. M. Mitov, E. Chorbadzhiyska, R. Rashkov, Y. Hubenova, Int. J. Hydrog. Energy 37, 16522 (2012)

13. M.A. Dominguez-Crespo, A.M. Torres-Huerta, B. Brachetti-Sibaja, A. Flores-Vela, Int. J. Hydrog. Energy 36, 135 (2011)

14. F. Bidault, D.J.L. Brett, P.H. Middleton, N. Abson, N.P. Brandon, Int. J. Hydrog. Energy 34, 6799 (2009)

15. R. Solmaz, A. Gundogdu, A. Doner, G. Kardas, Int. J. Hydrog. Energy 37, 8917 (2012)

16. E. Verlato, S. Cattarin, N. Comisso, A. Gambirasi, M. Musiani, L. Vazquez-Gomez, Electrocatalysis 3, 48 (2012)

17. A.J. Motheo, S.A.S. Machado, F.J.B. Rabelo, J.R. Santos Jr., J. Braz. Chem. Soc. 5, 161 (1994)

18. J.W. Kim, S.M. Park, J. Korean Electrochem. Soc. 8, 117 (2005)

19. J. van Drunen, T.W. Napporn, B. Kokoh, G. Jerkiewicz, J. Electroanal. Chem. 716, 120 (2014)

20. V. Paserin, S. Marcuson, J. Shu, D.S. Wilkinson, Adv. Eng. Mater. 6, 454 (2004)

21. M. Grden, M. Alsabet, G. Jerkiewicz, ACS Appl. Mater. Interfaces 4, 3012 (2012)

22. J. van Drunen, B. Kinkead, M.C.P. Wang, E. Sourty, B.D. Gates, G. Jerkiewicz, ACS Appl. Mater. Interfaces 5, 6712 (2013)

23. J. van Drunen, B.K. Pilapil, Y. Makonnen, D. Beauchemin, B.D. Gates, G. Jerkiewicz, ACS Appl. Mater. Interfaces 6, 12046 (2014)

24. A.A. Abd-El-Latif, E. Mostafa, S. Huxter, G. Attard, H. Baltruschat, Electrochim. Acta 55, 7951 (2010)

25. X.H. Xia, H.D. Liess, T. Iwasita, J. Electroanal. Chem. 437, 233 (1997)

26. J.F. Gomes, B. Busson, A. Tadjeddine, G. Tremiliosi-Filho, Electrochim. Acta 53, 6899 (2008)

27. A.A. El-Shafei, M. Eiswirth, Surf. Sci. 604, 862 (2010)

28. B. Pierozynski, Int. J. Electrochem. Sci. 7, 3327 (2012)

29. E.S. Switzer, T.S. Olson, A.K. Datye, P. Atanassov, M.R. Hibbs, C.J. Cornelius, Electrochim. Acta 54, 989 (2009)

30. G. Li, P.G. Pickup, J. Power Sources 173, 121 (2007)

31. S.S. Gupta, S. Singh, J. Datta, Mater. Chem. Phys. 120, 682 (2010)

32. F. Vigier, C. Coutanceau, F. Hahn, E.M. Belgsir, C. Lamy, J. Electroanal. Chem. 563, 81 (2004)

33. B. Pierozynski, T. Mikolajczyk, Electrocatalysis 7, 121 (2016)

34. B. Wu, M. Gong, J. Chu, X. Wang, S. Xiong, Ind. J. Chem. 52A, 1557 (2013)

35. B. Pierozynski, T. Mikolajczyk, Electrocatalysis 6, 51 (2015)

36. B. Pierozynski, T. Mikolajczyk, I.M. Kowalski, J. Power Sources 271, 231 (2014)

37. J.R. Macdonald, Impedance spectroscopy, emphasizing solid materials and systems (John Wiley \& Sons, New York, 1987) 
38. B. Pierozynski, T. Mikolajczyk, M. Turemko, Electrocatalysis 6, 173 (2015)

39. M. Alsabet, M. Grden, G. Jerkiewicz, Electrocatalysis 2, 317 (2011)

40. M. Alsabet, M. Grden, G. Jerkiewicz, Electrocatalysis 5, 136 (2014)

41. M. Alsabet, M. Grden, G. Jerkiewicz, Electrocatalysis 6, 60 (2015)

42. A. Zolfaghari, B.E. Conway, J. Electroanal. Chem. 488, 151 (2000)
43. S. Cherevko, A.R. Zeradjanin, G.P. Keeley, K.J.J. Mayrhofer, J. Electrochem. Soc. 161(12), H822 (2014)

44. S.S. Mahapatra, A. Dutta, J. Datta, Electrochim. Acta 55, 9097 (2010)

45. A. Lasia, A. Rami, J. Appl. Electrochem. 22, 376 (1992)

46. L. Chen, A. Lasia, J. Electrochem. Soc. 138, 3321 (1991)

47. J.J. Huang, W.S. Hwang, Y.C. Weng, T.C. Chou, Mater. Trans. 50(5), 1139 (2009) 